\title{
Jews, punk and the Holocaust: from the Velvet Underground to the Ramones - the Jewish-American story
}

\author{
JON STRATTON
}

\begin{abstract}
Punk is usually thought of as a radical reaction to local circumstances. This article argues that, while this may be the case, punk's celebration of nihilism should also be understood as an expression of the acknowledgement of the cultural trauma that was, in the late 1970s, becoming known as the Holocaust. This article identifies the disproportionate number of Jews who helped in the development of the American punk phenomenon through the late 1960s and 1970s. However, the effects of the impact of the cultural trauma of the Holocaust were not confined to Jews. The shock that apparently civilised Europeans could engage in genocidal acts against groups of people wholly or partially thought of by most Europeans as European undermined the certainties of post-Enlightenment modernity and contributed fundamentally to the sense of unsettlement of morals and ethics which characterises the experience of postmodernity. Punk marks a critical cultural moment in that transformation. In this article the focus is on punk in the United States.

We're the members of the Master Race

We don't judge you by your face

First we check to see what you eat

Then we bend down and smell your feet

(Adny Shernoff, 'Master Race Rock', from The Dictators' The Dictators Go Girl Crazy! [1975])

It is conventional to distinguish between punk in the United States and punk in England; to suggest, perhaps, that American punk was more nihilistic and English punk more anarchistic. Clinton Heylin writes that:

Much - indeed too much, too soon - has been written about the similarities between American and British punk scenes. The differences were considerable. (Heylin 1993, p. xiii)

Discussions about punk often get bogged down in nationalistic debates over the extent to which English punk owed its existence to American punk. This argument is often personified in the question of how much Malcolm McLaren learnt from the New York Dolls, and whether he stole the basic clothing style for punk in England from Richard Hell. In other words, discussions of punk have tended to focus either on a history located in individuals and influences or, much more rarely, on the immediate social context of punk and the more general consequences. The former approach tends to be used for American punk and the latter for English punk. However, these are only tendencies. While Roger Sabin's edited collection, Punk Rock: So What? (Sabin 1999) concentrates on the context and cultural consequences of punk in England, Craig O'Hara attempts to elucidate The Philosophy of Punk (O'Hara 1999) from its American history.
\end{abstract}


The literature on punk has ignored broader questions about the cultural causes and contexts for punk that might suggest why it broke through as an attitude to life at pretty much the same time on both sides of the Atlantic and, indeed, in other countries of the 'Western', modernised world. It is these more fundamental issues that I wish to address in this article. I want to suggest that punk evolved in the United States and England, and across the West more generally, most fundamentally and crucially as a pre-cursive expression of the cultural trauma of the Holocaust as this trauma began to enter what might be described as the cultural consciousness of the West. As we will see, the term 'Holocaust' did not become common as the way to describe the destruction and extermination of European Jewry until the late 1970s. Punk pre-dates this. In this article, therefore, I shall use the term 'Judeocide' to signal that during the original punk era the events that were subsequently narrativised as the Holocaust did not yet have a name. As part of my argument I will discuss the surprising number of Jews involved in punk through the 1970s.

The idea of cultural trauma has begun to gain significant currency recently. Ron Eyerman writes that:

As opposed to psychological or physical trauma, which involves a wound and the experience of great emotional anguish by an individual, cultural trauma refers to a dramatic loss of identity and meaning, a tear in the social fabric, affecting a group of people that has achieved some cohesion. (Eyerman 2001, p. 2) ${ }^{1}$

In the case of the Holocaust I am suggesting that two groups were culturally traumatised. First, the Jews; the decimation of the Jews of Europe inevitably had a traumatising effect on the remaining Jews across the world, and the following generations, not only on those conventionally described as Holocaust survivors. Second, on the population of the West more generally; with the events that we now understand as the Holocaust, key assumptions, including, for example, notions of social progress and civilisation that underpinned European modernity, were challenged and unsettled. ${ }^{2}$ As Jean-Francois Lyotard, among others, has argued, the Holocaust marks a fundamental moment in the transition from modernity to postmodernity, where one aspect of the postmodern is the putting into question of the certainties that underlie modernity. ${ }^{3}$

Cultural trauma, like individual trauma, is intimately bound up with the processes of memory. Cathy Caruth argues that: 'The story of trauma [...] as the narrative of a belated experience, far from telling of an escape from reality - the escape from a death, or from a referential force - rather attests to its endless impact on life' (Caruth 1996, p. 7). Commenting on Caruth, Eyerman notes that:

it is not the experience itself that produces traumatic effect, but rather the remembrance of it. In [Caruth's] account there is always a time lapse, a period of 'latency' in which forgetting is characteristic, between an event and the experience of trauma. (Eyerman 2001, p. 3)

If we apply this idea socially to the Holocaust, punk can be understood as the less or more choate, affective expression of the cultural trauma of the Holocaust as it surfaces into memory and cultural consciousness, and into representation.

\section{Glam rock to punk}

Anthony Rotundo argued some time ago in 'Jews and Rock and Roll' (Rotundo 1982) that Jews were, to all intents and purposes, absent from this musical form. However, 
they were most definitely present in punk, and in its highly visible, spectacular precursor, glam rock. Of course, this begs the question of when we might want to claim punk begins as a musical form, and indeed as a musical expression of a way of thinking about the world or, more particularly, the Western way of life. If, as is conventional in American popular music criticism, we take the Velvet Underground as a key marker in the development of punk, their first album The Velvet Underground and Nico having been released in 1967 (Heylin [1993, p. 3] writes of '[t]he revolution instigated by The Velvet Underground and Nico'), then early punk precedes glam. In England, glam was epitomised by Marc Bolan's transformation of his band Tyrannosaurus Rex into T. Rex (the album T. Rex was released in 1970), and in the United States by the release of KISS's first album, KISS, in 1974. What we can say, then, is that, while in terms of popularity glam preceded punk, especially in England, generically the two musical forms developed about the same time and coexisted.

The Jews who became pioneers of glam rock were the same generation as the Jews who helped to develop punk. This was the first generation after the Judeocide. In Coming Out Jewish I argued that, through modernity, within the new nation-states, Jews strove for invisibility, that for 'the migrant or minority group [the tactic of invisibility works] to enable them to live unnoticed, unremarked on, within the general population' (Stratton 2000, p. 102). The post-Judeocide generation, consciously or not, knew that invisibility was no longer an option. Invisibility, confining Jewishness to the home, or giving away all formal sense of Jewishness and becoming Christian, still would not save them. It had not saved the assimilated Jews of Germany, and the rest of Europe, from the Nazi death camps. These secondgeneration post-Judeocide Jews knew that the dominant social order could always renege on the assimilatory bargain. The Jews involved in glam rock may not have thought about it consciously, but they were making themselves visible in the most spectacular way - even if, as had been common in modern Europe, they changed to less obviously Jewish names. Here we can see how complex was the process of coming to terms with the recognition that invisibility was no longer an acceptable choice. On the one hand, these Jews made themselves highly visible, on the other hand they continued with the assimilationist, invisibility tactic of changing their names. These Jews may not have overtly flaunted their Jewishness but they established their public presence in the most spectacular way. Glam rock evolved contemporaneously with punk, though punk remained a relatively cult form until, in England much more than in the United States, punk was popularised, or at least spectacularised, through the managerial genius of Malcolm McLaren and, to a more limited extent, that of his friend, colleague and manager of the Clash, Bernie Rhodes. McLaren's mother was Jewish. Rhodes' mother was not only Jewish, she was a Holocaust survivor.

While, from a Jewish point of view, glam rock was concerned with issues of visibility, punk, in part, and especially in its American incarnation, was, I will be arguing, informed at a deep level by the trauma of the Judeocide. Both preoccupations were a product of that event. ${ }^{4}$ The philosophical attitude expressed by the two genres was quite distinct. Where glam was more concerned with style and gender issues, punk was much darker, acting out, for Jews at least, the experience of the cultural trauma of the Judeocide. Through the 1950s and 1960s this had continued to be repressed. Peter Novick, in his important history of the changing attitudes to the Judeocide, The Holocaust in American Life, writes that, 'the Holocaust wasn't talked about very much in the United States through the end of the 1950s. [. . .] it's been talked about a lot since the end of the 1970s' (Novick 1999, p. 127). From the point of 
view of the acting out that was related to the repression of the Judeocide, punk was a more profound movement than glam. However, from a Jewish point of view, glam made Jews highly visible, stating, albeit unconsciously, that, in contradiction to the attempts of the Nazis, Jews continued to exist.

Some people recognised the connections between these two apparently diverse subcultural forms. In England, with the advent of punk, Marc Bolan began to be described as a 'cosmic punk' and, in 1977, he invited the Damned, who had put out the first English punk single, to tour with him. Captain Sensible expressed his admiration for Bolan, saying that " "His music said it all [. . .] He went out on a limb, destined to make weird records with weird lyrics, doing something nobody else could understand"' ' (quoted in Paytress 1992, p. 254). David Thomas, a part of the Cleveland punk scene and a member of the (post-)punk band Pere Ubu, suggests that in the United States:

Marc Bolan was seen as an underground thing and not as a teenybopper. Musically Marc Bolan was considered to be, quite rightly, a real radical 'cause he was producing a psychodramatic musical form and this is what we were picking up on, not all the teeny trash. What he was doing he was doing incredibly intensely. (quoted in Heylin 1993, pp. 147-8)

Thomas isn't explicit about what psychodrama Bolan was acting out. However, Bolan's father was Jewish, his given name was Mark Feld. ${ }^{5}$ Born in 1947, Bolan remained closely allied to the Jewish experience, and the problems of assimilation, throughout his life. After he died in a car accident in September 1977, Bolan was cremated in a Jewish ceremony at Golders Green Crematorium in north London. It is reasonable to conjecture that the psychodrama that Thomas reads out of Bolan's work is founded on the cultural trauma of the Judeocide.

In the United States the Ramones came from a glam rock background. As Everett True notes in his biography of the Ramones: 'All four future Ramones attended early Seventies glam rock clubs in Manhattan, and dabbled in the look of the time' (True 2002, p. 17). More specifically, the Jewish Joey Ramone, born Jeffrey Hyman, had played in a glam rock band called Sniper. At that time he called himself Jeff Starship, clearly an ironic reference to Jefferson Starship, the 1970s stadium rock version of the 1960s countercultural, San Francisco band, Jefferson Airplane. Andy (aka Adny) Shernoff, of the proto-punk band The Dictators, remembers that Joey 'looked a little like Freddie Mercury' (quoted in True 2002, p. 29). ${ }^{6}$

In the United States, the most important glam rock band was KISS. The two founding members of KISS, Gene Simmons and Paul Stanley - Chaim Witz and Stanley Eisen, respectively - who started the band around 1973, were both Jewish. However, the American band that most demonstrated the overlap between glam and punk was the New York Dolls. Jon Savage writes of founding members Sylvain Sylvain, Johnny Thunders and Billy Murcia that they were: 'Clothes obsessives and Anglophiles, [...] teenage hedonists trying to find a way into [the New York club] Max's Kansas City' (Savage 1992, p. 59). The group came into being in 1972. They wore drag and were connected to the transvestite scene associated with Andy Warhol. At the same time, musically:

Alongside Johansen's burlesque, Jagger-like leers, Johnny Thunders' guitar slid in a series of drones that, like John Cale's viola in the Velvet Underground, gave an edge of harmonic instability - you never knew when they would explode. Beneath this near-chaos was Arthur Kane's bass, which thudded along on the beat in a minimum of notes. (Savage 1992, p. 60)

The band was way more punk than glam. When The New York Dolls toured England and Europe in late 1973, McLaren followed the tour (ibid., pp. 82-3). A year later he 
had an informal arrangement with the band to be their manager, and he became their fashion advisor. Sylvain Sylvain of The New York Dolls is Jewish. His given name is Sil Mizrahi. He was born in Cairo and his family left Egypt in the anti-Jewish backlash after the Suez Crisis in 1956. At one point, when the Dolls were disintegrating, McLaren asked Sylvain if he would like to front the Sex Pistols.

Turning to the origins of punk, in the Velvet Underground the singer and lyricist Lou Reed was Jewish. As we shall see, it was no coincidence that the Velvet Underground was Sylvain's favourite band when he was growing up. ${ }^{7}$ Heylin remarks that, ' $\mathrm{i}] \mathrm{f}$ the Velvets were operating outside conventional parameters, they did not see themselves as working entirely in a vacuum' (Heylin 1993, p. 21). He goes on to quote Sterling Morrison, guitarist with the Velvets, identifying the Fugs and the Holy Modal Rounders as 'authentic Lower East Side bands' who were also experimenting with the limits of popular music. Tuli Kupferberg, one of the co-founders of the Fugs in 1965, is Jewish. Kupferberg was a published Beat poet and political radical. He is a connection between the history of Jews in post-war American radical politics and so-called protest music, and the punk experience. Jonathan Richman and the Modern Lovers' self-titled first album was recorded in 1973, and produced by John Cale of the Velvet Underground. Hailing from Boston, Richman is Jewish. That first, ground-breaking album lifted off from the Velvet Underground's music. On the sleeve-notes for The Original Modern Lovers 1981 compilation, Richman writes that: 'If it weren't for [Iggy] and Lou Reed this record wouldn't have existed' (quoted in Heylin 1993, p. 44). Although not released until 1976, with its urban angst expressed both lyrically and sonically, The Modern Lovers is a link between the Velvets and the later American punk bands.

Richard Hell, born Richard Meyers, had a Jewish father from the German-Jewish community in Pittsburgh. He died when Hell was seven. Hell co-founded Television with Tom Verlaine in 1974. This band was also influenced by the Velvet Underground. Hell left Television in 1975, before the release of the band's first album in 1977, the highly-regarded Marquee Moon. Hell subsequently wrote and performed the punk anthem 'Blank Generation' with the Voidoids. He took his pseudonym from Arthur Rimbaud's book of traumatised poetry and short prose, Un saison d'enfer, 'A Season in Hell', first published in French in 1873. Verlaine and Hell had been schoolfriends. Verlaine's given name was Tom Miller. He called himself Tom Verlaine after the poet who had been Rimbaud's lover. ${ }^{8}$ Hell did not call himself Richard Rimbaud. His choice has a more traumatic resonance. Hell also developed the spiked hair and torn T-shirt style that, it is said, McLaren appropriated and popularised as the basis for English punk style. Hell's most celebrated T-shirt slogan was 'Please Kill Me'.

In the course of this article we shall meet other American Jews who played important roles in the formation and expression of punk. For example, there were members of Blue Öyster Cult and The Dictators, and especially the manager of both these bands, Sandy Pearlman, who also wrote lyrics for BOC and co-produced or produced nine of their albums. In addition, Pearlman produced the Clash's second album, Give 'em Enough Rope (1978). One important difference in the positioning of Jews in punk between England and the United States is that there were fewer Jewish performers in England. They tended more to managerial and entrepreneurial roles, as Jews had in the English entertainment industry for a couple of generations. One reason for this was the pressure in England to assimilate. ${ }^{10}$ McLaren modelled his managerial career on that of the Jewish Larry Parnes who had been central to the development of rock ' $n$ ' roll in England, discovering most importantly Billy Fury. In 
1977, when the major record companies were refusing to sign the Sex Pistols, Parnes contacted McLaren and offered to set up his own label especially to release the group's material (Savage 1992, p. 341). Brian Epstein, who managed the Beatles, was also in this English, Jewish managerial tradition.

In the United States where, in spite of anti-semitism, Yiddish culture was more established as an element in the migrant mix that made up the American population, there was a relatively greater number of Jewish practitioners in punk - as well as a large number of managers, record company executives and the like. There was, for example, the Stooges' manager, Jimmy Silverman (also known as Jimmy Silver), and Danny Fields, the A\&R man who signed the Stooges to Elektra. Seymour Stein, who founded Sire Records in 1966, was one of the first record company executives to appreciate punk. He signed the Ramones, Richard Hell and the Voidoids, the Dead Boys, and Talking Heads.

\section{The Jewish context for punk}

Victor Bockris, who has written biographies of the Velvet Underground and Blondie, is quoted in Everett True's book on the Ramones:

Punk was the last great reaction to the Second World War [. . . A After the war, you had the Beat generation, the abstract expressionists, Francis Bacon, and those great Fifties artists. Then it was the Sixties, the rock'n'roll generation. I was born in 1952. My generation, the punk rockers, grew up totally affected by the war. All our comic books, our games, our films were about it. The reason the punks wore Nazi uniforms and flirted with fascist iconography was the same reason the Stones had. It was like, 'Stop fucking telling me about the war'. (True 2002, p. 59)

In England, Siouxsie Sioux made a similar comment to Jon Savage. Savage writes:

If there was one symbol of this nightmare [chaos, incipient fascism, violence, no future], it was the Punk use of the swastika. 'It was always very much an anti-mums and anti-dads thing', says Siouxsie. 'We hated older people - not across the board but particularly in suburbia - always harping on about Hitler, 'We showed him', and that smug pride. It was a way of saying, 'Well I think Hitler was very good, actually': a way of watching someone like that go completely red-faced. (Savage 1992, p. 241)

Sioux's rejection of the war generation's easy self-satisfaction spills over here into a problematic proto-fascism.

The link between Hitler, World War II, and the Judeocide would seem to have been naturalised. In a notorious early song, 'Love in a Void', Sioux sang:

Too many Jews for my liking

Too many critics too few writing

In later renditions of the song the line was changed. In her 1978 review of Siouxsie Sioux and The Banshees' first album, The Scream, in New Musical Express, Julie Burchill wrote:

['Love in a Void'] featured the line 'Too many Jews for my liking'. This, says Siouxsie, was a metaphor for too many fat businessmen waiting to pounce, suck the youth from and cast aside new talent.

I do not see the connection. I, self-righteous square that I am, consider 'Too many Jews for my liking' to be the most disgusting and unforgiveable lyric-line ever written, though God knows there has been more appalling filth written within rockanroll than in every other branch of the entertainment business taken together. (Burchill 1978) 
Sioux's gloss, as offered by Burchill, does not deny the attack on Jews. It simply focuses it. Indeed, Sioux may well have been thinking of McLaren and Rhodes, and maybe that lineage of Jewish entertainment impresarios in England including, for example, the Grade family. One point to make here is about how the attack on English suburban smugness in respect of the war so easily spills over into an ingrained anti-semitism. Another point is that Burchill's reaction, her horror at the line even in the context of punk nihilism, suggests the informing moral power of the Judeocide.

At this point we need to put punk into a historical context. Bockris does not mention Jews; as is common in discussions of punk, they are elided. However, punk appears at a time when the Judeocide is just entering the popular Western cultural consciousness. While there was a trickle and then a stream of novels, autobiographies and other accounts that dealt more or less directly with the Judeocide but which, during the 1950s and 1960s had only minority appeal, in popular music, where commercial demands meant that music needed to appeal to large numbers of record buyers, during the 1960s and 1970s there developed something more than an elective affinity between punk and the Judeocide. Punk marks the confrontation with the Judeocide in popular culture, and popular consciousness.

The Israeli trial of Adolf Eichmann, which went a long way to publicising what happened to the victims of Nazi extermination, took place between April and November 1961. Hannah Arendt's book of the trial, Eichmann in Jerusalem: A Report on the Banality of Evil, which had originally appeared as articles in The New Yorker, was first published in 1963 and republished in an enlarged edition in 1965 suggesting its popularity (Arendt 1994). The television series which told the story of the Judeocide, and popularised the term 'Holocaust' for it, Holocaust: The Story of the Family Weiss, was shown in the United States and across Europe in 1978. In between, setting punk aside for a moment, there were a number of second-generation - that is Jews born either late in the war or afterwards - Jewish attempts to acknowledge the catastrophe in popular music. An English-speaking Jew from French Canada, Leonard Cohen, who became a major singer-songwriter after the release of his first album Songs of Leonard Cohen in 1967, published his third book of poems entitled Flowers for Hitler in 1964. While this was more 'High Culture', Cohen was travelling towards a popular audience. His first novel, The Favourite Game, had his Jewish protagonists playing Nazi torture games. His second novel, Beautiful Losers, was published in 1966 and gained a cult audience. Norman Rawin writes that, 'near the end of Beautiful Losers, Cohen makes a more prolonged and startling use of the Holocaust than any appearing in his other writings' (Rawin 1993). These novels were popular in countercultural circles. Released a year later, Cohen's first album of songs was bleak and angst-ridden, though there were no direct allusions to the Judeocide. Kinky Friedman, the Texan Jewish country and western singer (later turned detective novelist) released the elegiac 'Ride 'em Jewboy' in 1973, a direct comment on the Judeocide. It contains lyrics such as:

Dead limbs play with ringless fingers A melody which burns you deep inside Oh, how the song becomes the singers May peace be ever with you as you ride

Two years later, in France, Serge Gainsbourg released Rock Around The Bunker. This included tracks like 'Nazi Rock' and 'SS in Uruguay'. Perhaps the most haunting is 'Yellow Star' in which Gainsbourg sings that: 'J'ai gagné la yellow star' (I have 
won/worn the yellow star). Gainsbourg was born in France in 1928 to Russian-Jewish immigrants. In 1942 he was indeed forced to wear the yellow star (Sylvie Simmons 2001).

The Jewish formative influence on punk as an unformed expression of cultural trauma was central to punk's development. Bockris (1996) concentrates on punk as a rejection of the constant preoccupation with Nazism that was imposed on the postwar generation. Savage describes punk as a white musical form which can express nihilism. Commenting on the proto-punk of American garage bands of the 1960s, he writes of:

a purely white, blue-collar style, in which any black rhythmic influence was bleached out in favour of pure noise and texture: fuzz guitar, feedback, drones and whinny vocals. The flatly rhythmic repetition of a song like? and the Mysterians' '96 Tears' seemed to be the perfect form through which to express a numb nihilism. (Savage 1993, p. 82)

But what is this existential nihilism of the white, American post-war generation? At one level it is the profound consequence of the modern trajectory towards a loss of transcendental meaning, Nietzsche's death of God:

Nietzsche regarded the contemporary onslaught on meaningfulness, of the umsonst, as a direct consequence of the collapse of the Christian moral interpretation of the world, a collapse brought about by the consistent application of its own moral hierarchy. The will to truth, fostered by Christianity above all else as the means whereby one acquires the proper relationship to the divine, ultimately turns against the metaphysical framework that made it intelligible, showing it to be false and untenable. (Carr 1992, p. 39)

Jill Marsden suggests that:

At bottom, the nihilist suffers a disappointed passion, a love of wisdom cruelly unrequited by an indifferent object of desire. The world of becoming exhibits the reality of the Schopenhaurian 'evil, blind will' in which satisfaction is constantly frustrated, its miserable subjects skewered on the wheel of Ixion for eternity. (Marsden 2000, p. 75)

The world offers, and makes, no sense in its own right. Within this context, punk in the United States and England expressed more immediate and localised concerns: in England a reaction against, among other things, rising unemployment under Harold Wilson's and James Callaghan's Labour governments ${ }^{11}$ followed by the stifling co-optation of everyday life under Margaret Thatcher's version of conservatism; in the United States a statement about the worth and relevance of popular culture for cultural critique and a criticism of the banality of suburban life which had been the post-war American dream; in both a critical engagement with stadium rock and the capitalist drive of the record companies.

At the same time the context for punk was the increasing recognition of the Judeocide as the founding caesura of a fundamentally nihilist culture. Avishai Margalit and Gabriel Motzkin describe how the Holocaust has become a negative origin myth. They write:

A negative myth of origin, in contrast to a positive one, means a myth that takes the moment of creation as a moment of chaos and destruction, and contrasts our order or disorder to that originary moment of chaos and destruction rather than to any well-ordered process of creation or stabilising harmony. The Holocaust has become such a foundational moment. (Margalit and Motzkin 1996)

Vladek Grjibovsky has glossed Theodor Adorno's thoughts on the metaphysical significance of the Holocaust and its relation to nihilism: After Auschwitz, the metaphysical question about the meaning of life and death yields to a historical question: 
'Is it still possible to have a metaphysical experience?' For Adorno this is because actual events - the Holocaust - have shattered the basis upon which metaphysical speculations might be reconciled with experience. The categories of metaphysics live on in the secularised and vulgar form in the question of the meaning of life, the very question that propels the problem of nihilism. (Grjibovsky [n.d.]) Punk marks the concatenation of all these micro and macro issues in the historical moment when the Judeocide was becoming discursively constructed as the Holocaust, as the site of a primal, transforming, cultural trauma.

\section{Punk and nihilism}

Savage argues that: 'The whole idea of Punk, as coined by [Dave] Marsh and [Lester] Bangs marked a process of deliberate unlearning; a new pop aesthetic that delighted "in Rock's essential barbarism (and the worth of its vulgarism)" ' (Savage 1992, p. 82). At that profound level, punk could be understood as the acting out of nihilism as initiated by and filtered through the surfacing cultural trauma of the not-yet-named Holocaust. Musically, the punk form pioneered by bands like the Stooges, the early MC5, the Electric Eels, early Pere Ubu, collapsed melody, the distinctive European musical style, into noise. ${ }^{12}$ These bands walked the line between order and chaotic destruction. Here too the Velvet Underground pioneered the way, first with 'Black Angel's Death Song', which will be discussed later, and then with the White Light, White Heat album (1967), most especially 'Sister Ray'. Jacques Attali argues that: 'With noise is born disorder and its opposite: the world. With music is born power and its opposite: subversion' (Attali 1985, p. 6). In European terms, if the world is born with the melodic organisation of noise that is described as music, then it ends with the loss of that organisation and the return of noise. The (certainty of the) modern world ended with the Judeocide.

Given this kind of understanding of 'music' and 'noise', it is not surprising that Lester Bangs, the American rock critic who most championed the genre of punk, should use terms associated with a transcendental End, and with the Judeocide, to comment on one of the most important progenitors of punk rock, Iggy Pop. Describing Pop's performance, Bangs writes that: 'An apocalypse isn't supposed to be manageable, and when the carnage is done it ain't the audience that's gonna be bleeding', and: 'A far more powerful documentation of the Iggy holocaust at its most nihilistically out of control is available on Metallic KO' (Bangs 2001, p. 206). Metallic $K O$ is a live Iggy and the Stooges album recorded at shows in 1973 and 1974. It was released in 1976. Implicitly, Bangs is implying that, in his performance, Iggy is embodying the nihilistic problematic of what James Young in Writing and Rewriting the Holocaust (1988) terms the Holocaust Jew.

Iggy Pop is not Jewish, though many people think he is, legitimating this by reference to his given name, James Osterberg. Writing about poetry, Young explains:

Of the generation of non-Jewish poets who identified literally as Holocaust Jews, the numbers [who committed suicide] are [...] disquieting. John Berryman, Randall Jarrell, Anne Sexton and Sylvia Plath all killed themselves after representing themselves literally in light of the Holocaust. (Young 1988, p. 127)

The identification with Jews who died in the Nazi extermination suggests an experience of extraordinary personal suffering, a suffering associated, for whatever reasons, with self-destruction. Iggy has never overtly represented himself as Jewish, 
let alone as a victim of the Holocaust. Indeed, he is known to have passed anti-Semitic remarks on a number of occasions, one of which is recorded on the live album to which Bangs refers, Metallic KO. Nevertheless, Iggy lived in the world with the same psychic structure as those who, in Young's term, overtly identified themselves as Holocaust Jews.

Iggy lived literally emotionally close to a Jewish identity. At least two of his major relationships have been with Jews. In his autobiography, I Need More, he describes how he married a Jew, Wendy Weisberg, when he was twenty-one or twenty-two: 'She was tomboyish, with a very, very beautiful build - a Jewish girl from Shaker Heights, a wealthy suburb of Cleveland' (Pop 1982, p. 37). Elsewhere in the book he writes:

I had a real home once. It was in Berlin. I lived there for two years, well really just over that. I had a residence for two years with a girl called Esther. (ibid., p. 99)

This was Esther Friedman, the Jewish daughter of an American diplomat. We shall return to the symbolic and emotional importance of Berlin later.

In Please Kill Me, Legs McNeill and Gillian McCain's oral history of American punk, Ron Asheton, who was in the Stooges, tells a long story about Iggy and Jewish girls. Asheton begins:

Iggy was such a mess. He was doing this whole thing of hooking up with rich Jewish girls. He had this really rich Jewish girlfriend whose name was Alex. (McNeill and McCain 1996, p. 436)

Asheton's point is that Iggy would 'really burn these girls'. Iggy's marriage only lasted a month. It seems his attitude to Jewish women was profoundly ambivalent, as was his attitude towards himself.

The two are combined in Iggy's narrative about how he became a self-mutilator on stage. Having met Wendy when he was nineteen, Iggy lost touch with her. A couple of years later she turned up without warning at an Iggy and the Stooges gig in Delaware, Ohio. The audience was very small, under twenty. Iggy really wanted to impress Wendy:

But I didn't feel enough response from the audience. Somehow, I guess it wasn't what I wanted. I didn't hear the bells ring or whatever. So in the second song, I started hurting myself - flinging myself about and hurting myself, messing myself with a drumstick. And, as I was doing it (it didn't hurt or anything), the music sounded better and better and better [. . . I felt very good. And then it was over. (Pop 1982, p. 38)

Iggy then discovers Wendy's reaction:

She was almost in tears. She had been crying. And she was angry, like 'How could you do that to me?' I felt so bad. I had never thought that anyone (except, of course, my mother and father) ever cared about me. (ibid., p. 39)

Iggy neither identifies himself as a Holocaust Jew nor commits suicide. ${ }^{13}$ However, his idea to enhance his performance by self-mutilation comes when the Jewish girl to whom he is strongly attracted first watches him perform. She feels, correctly, that Iggy's self-mutilation is directed at her. ${ }^{14}$

What is the meaning of this self-mutilation that becomes a regular aspect of Iggy's act? We have noted Bangs describing the act in terms of apocalypse, nihilism and holocaust. Here, at the moment of its inception, we find it associated with a Jewish woman. Margalit and Motzkin argue that:

it is exceedingly rare and maybe unique that a group of people have been both systematically humiliated and systematically killed. The combination of humiliation and destruction helps 
explain the perverse fascination with the Holocaust, which partly resembles the fascination with rape and murder. (Margalit and Motzkin 1996)

Iggy was acting out the emotional structure of the Holocaust Jew for this secondgeneration post-Holocaust Jew whom he desired. We can begin to appreciate the complexities, most of which no doubt Wendy herself was not aware of, especially given the historical moment, around 1970, hidden in her response. ${ }^{15}$

It is not surprising, then, that visiting Wendy in her Shaker Hills apartment, 'was the first time [Iggy] really listened to the song "Heroin", by Lou Reed' (Pop 1982, p. 39). Reed is Jewish, born Louis Firbank into a middle-class Brooklyn family in 1942. We shall meet him again later in the Velvet Underground. Jeremy Reed describes 'Heroin' as 'a death spiral, but a highly creative one' (Reed 1994, p. 4). He elaborates on this:

[Reed's] urgency and heroin's right-out-of-it laid-back oblivion are a refuge, and a means of magnifying the stupidity of war-bent politicians. The junkie couldn't care less. The dead bodies pile up in mounds, but they don't reach the precincts of inner space. (loc. cit.)

Here, again, we have the internalised destruction and the retreat from a reality that is too awful to contemplate. As Jeremy Reed indicates, one of the things that the junkie first person narrator no longer cares about after he has shot up is: 'all the dead bodies piled up in mounds'. This reference, in the context of the 1960s, suggests the wellknown photographs taken in the Nazi death camps immediately after they were liberated. Of course, Reed was most probably not consciously making the connection in these lyrics. Rather, given his Jewish background and the awareness of these photographs and what they referred to, it would be understandable that he might conjure this image in a song that is often read as celebrating the numbing effects of heroin.

When Iggy and Wendy got married, Ron Asheton, the guitarist with the band, was best man. As Asheton describes it:

I wore my Luftwaffe fighter pilot's jacket, with a white shirt, with a Nazi Knight's Cross with oak leaves and swords. On the jacket I had my Iron Cross first class, the ribbon bars, the Russian front Iron Cross second class, and my riding boots and jodhpurs.

[...] Our manager, Jimmy Silver, who is Jewish, was best man. (McNeil and McCain 1996, p. 52)

Iggy remembers Asheton's costume with an important difference: 'He was dressed in a full SS colonel's uniform - a real one - from head to toe' (Pop 1982, p. 40). In Iggy's memory, Asheton wore the stereotypical Nazi uniform, and the uniform of those who had the special responsibility for the Final Solution. We can only surmise the complexities of Wendy's feelings about this wedding - which her parents refused to attend.

Given that Iggy had the emotional structure of a Holocaust Jew, then it is understandable that Danny Fields who, as I have noted, signed the Stooges for Elektra, should have been so ecstatic about discovering the band. In the liner notes for the 1988 re-issue of the Stooges' self-titled first album, Fields writes that, when he first saw the band, 'I couldn't believe what I was seeing and hearing, a cliché I know, but real for me on that first night of autumn in 1966. I had never seen a performer as incredible as Iggy [...] and about the music, I could only say, "At last'" '. Why, 'at last'? I would argue that the Jewish Fields found in Iggy the scream of traumatised agony, the experience of self-disgust and the urge to 
self-destruction, that mirrored what he felt at some deep and, at that time most probably unacknowledged, level.

\section{The Jew/Nazi dyad in punk bands}

Asheton was a collector of Nazi memorabilia. There is an intriguing structural similarity between many of the major American glam and punk bands that contained Jews. This is that these bands often also contained a member who was fascinated by the Nazi era. In addition, in these bands, and I am including Iggy and the Stooges here because of Iggy's unconscious Holocaust Jew identification, the Jew was the lead singer. Indeed, he - and they were always male - was also a major lyricist for the band. The Jewish member of these bands was very often a founding member, and a guiding force in their self-understanding and presentation. He was also the most visible of the band members, as the singer fronting the band.

As an early example of this, we have the Velvet Underground and Nico. Certainly, the much-troubled Nico was not a Nazi but she was a German unable to reconcile her childhood in Nazi Germany, she was born in 1938, with her later knowledge of the Nazi attempt to exterminate the Jews. I will return to Reed and Nico later - for the moment I want simply to point out the structural relation which, it should be added, lasted only for the eponymous first album. Secondly, there is Iggy Pop and Ron Asheton whom I have already discussed. In I Need More, Iggy tells a story about a gig in New Jersey where:

Ron's dressed up in his SS outfit. I had goaded Ron into doing a German language introduction to our set. I told him people would love it, in full SS gear right? (Pop 1982, p. 82)

In a significant echo of what Wendy said to him after his first public self-mutilation, Iggy recounts, 'a little kid in front saying, "'How could you do this?" pointing at the SS gear'. Displacing his anxiety in telling this story, Iggy rather bizarrely offers: 'It must have been an Italian kid' (ibid., p. 85). To recognise 'the kid' as very likely Jewish might have been too confrontational.

In the glam band KISS, the co-founder and front-man, Gene Simmons, was Jewish. Simmons' mother was Hungarian. She was sent to a concentration camp when she was fourteen (Gene Simmons 2001, pp. 6-7). Simmons was born in Israel and spent his early childhood there. The lead guitarist that he and the other co-founder, the Jewish Paul Stanley, chose for the band was Paul Frehley, known as Ace. As Simmons tells the story in his autobiography, while Ace's music complimented the band well, his general demeanour was problematic. Ace is described at one point as 'as infuriating as ever' (ibid., p. 158). Simmons offers many examples of Ace's uncooperativeness - and of his constant need to discipline him. Ace, we are told, 'had a fascination with Nazi memorabilia, and in his drunken stupors he and his best friend would make videotapes of themselves dressed as Nazis' (ibid., p. 128). Simmons also tells this story from KISS's Japanese tour in 1977:

One night he knocked on my door and appeared in front of me drunk out of his mind in full Nazi uniform with his friend, saluting and yelling into my face: 'Heil Hitler!'. I have pictures. Ace knew how I felt about Nazi Germany. He knew that my mother had been in the concentration camps and that her whole family had been wiped out. But that didn't stop him. (ibid., p. 134)

Simmons has the attitude of an Israeli sabra - a Jew born in Israel. The view that in their European past, and especially during the Judeocide, Jews had allowed 
themselves to be pushed around too much and that now they should stand up for themselves.

Simmons tells us how, after moving to the United States, he became hooked on comic books, reading Superman and Batman - superheroes (ibid., p. 32). Joe Schuster and Jerry Siegal, two Jews from Cleveland, created Superman, the first superhero, in the 1930s. Superman can be viewed as a refugee from a catastrophe who learns to fit in by hiding his special powers, an almost uncanny echo of the experience of the Jewish migrants from the Pale to the United States, and the Judeocide that was just getting under way - though we should also remember that turn-of-the-century Jewish migration was precipitated by horrifying pogroms that were, themselves, at that time considered by Jews to be a monumental disaster. When KISS started wearing make-up, Simmons' style was taken from Black Bolt, 'a character in the Marvel comic The Inhumans' (ibid., p.74), while elements of his costume were drawn from Batman and Phantom of the Opera. Black Bolt was the king of the Inhumans. He could harness electron manipulation to increase any aspect of his physical nature, especially his strength. Similar to his superheroes' worldview, Simmons seems to have felt that he had to live with evil in his own band, dominating it every day. With the band working through the emotional resonance of the Judeocide, it is not surprising that their fans should be called the 'KISS army', or that in their KISS logo the two 's's should so closely resemble the 's's as lightening bolts on Nazi SS uniforms.

Another band with this structural relation was the Ramones. Their self-titled first album was released in 1976. I have already noted Joey Ramone's Jewish background, and his musical heritage in glam rock. He was originally the drummer in the band but became the singer. Dee Dee Ramone was the bass guitarist. Dee Dee was born Douglas Glenn Colvin in 1952. His father was a career soldier who had fought in the Second World War at the Battle of the Bulge, and in the Korean War. ${ }^{16}$ Dee Dee spent almost all his childhood and early teen years in Germany where his father was stationed. True writes that: 'For recreation, Dee Dee would scour the old war fields for Nazi paraphernalia to sell to visiting American soldiers - bullets, gas masks, bayonets, helmets' (True 2002, p. 15). Around the same time Dee Dee began using drugs and acquired what turned into a fourteen-year heroin addiction. When Tommy Ramone, the drummer, and later producer for the band, wrote a song called 'Animal Hop' based on Bay City Rollers-style pop like 'Saturday Night', it was Dee Dee who gave it its Nazi overtones, renaming it 'Blitzkrieg Bop' and altering the line 'They're shouting in the back now' to 'Shoot 'em in the back now' (ibid., p. 59).

It was Dee Dee who provided the band's nihilist negativity, writing, for that first album, 'I Don't Wanna Walk Around With You', 'Now I Wanna Sniff Some Glue', and the unwittingly insightful, 'I Don't Wanna Go Down To The Basement'. True suggests that this song was 'directly inspired by Seventies slasher movies' (ibid., p. 60). However, it also suggests an anxiety about what was in Dee Dee's own unconscious and, indeed, that of the band as a whole. A preoccupation with death spreads across the entire album. The tone, and reference point, for the album is established by the first track, 'Blitzkrieg Bop'. This is followed by 'Beat on the Brat', a straightforward invocation to violent aggression. The next track is 'Judy Is a Punk'. True writes that this is about two juvenile delinquents who were Ramones fans (ibid., p. 60). The song namechecks Berlin and then claims that Judy and Jackie went to San Francisco where they joined the SLA. The Symbionese Liberation Army was the American revolutionary terrorist group who are best known for kidnapping Patti Hearst in 1974. Each 
verse of the song ends with 'Perhaps they'll die'. The final song on the album returns us to the Nazi theme. It is called 'Today Your Love, Tomorrow the World'. Written in the first person, it is about a Nazi 'shock trooper in a stupor' - perhaps one of the ones referenced in the third person in 'Blitzkrieg Bop'.

By the album's conclusion it is clear that the nihilistic malaise of violence and death which pervades the lyrics, and which is counterbalanced by the power, energy and sheer melody of the music, has its psychological roots in what the Ramones present as the Nazi worldview. All these songs, we need to remember, are sung by Jewish Joey Ramone. While the Judeocide is, as in most punk lyrics, not mentioned, there is a repressed tension in the lyrics of Nazi domination - 'Tomorrow the World' being sung by a Jew. This tension was only resolved in 1985 when Joey, with help from Dee Dee, wrote 'Bonzo Goes To Bitburg' about then-President Ronald Reagan's scandalous visit to a West German cemetery containing SS graves. By then, the discourse of the Holocaust was well-established and the nihilistic complexities of punk much more resolvable, at least to the extent that they were grounded in the Judeocide.

What pervades all these versions of the Jew/Nazi structural relation as it gets played out in various ways in all these bands, is an anxiety over domination and subordination. Sometimes this was expressed in lyrics displaced by being given a sexual basis. Lou Reed's lyrics frequently express this dynamic. On The Velvet Underground and Nico there is 'Femme Fatale', a song he wrote for Nico to sing. Here, 'she' / Nico is the strong woman who holds men in thrall, who is 'just a little tease' and with whom 'Before you start, you're already beat'. On the same album there is Reed's paen to masochism, 'Venus in Furs'. As is well known, the title is taken from the story of the same name written in German by Leopold Sacher-Masoch. The lyrics move between third and first person, uncertainly placing the singer, Reed, in the position of the person taking pleasure in his own domination. With Nico as German, and Venus in Furs having been written by a German, we can construct an image of Reed as an anxious post-Judeocide Jew dealing with the then-dominant image of Jewish passivity in the face of Nazi extermination - an anxiety played out in Nico and Reed's relationship. Again, this is not to suggest that Reed consciously wrote these lyrics with this understanding. Rather, given their respective backgrounds, he, and Nico, were acting out a cultural trauma which was just beginning to surface.

Blue Öyster Cult are not usually classified as a punk band. Rather, as a rule they are thought of as early American heavy metal. Nevertheless, some of their lyrical concerns, if not their musical style, ally them to punk and, as I have noted, their manager and sometime lyricist, Sandy Pearlman, also managed The Dictators and produced the Clash's second album. It is unclear how many of Blue Öyster Cult were Jewish, certainly (again) the lead singer, Eric Bloom, and it would seem, some if not all of the rest of the band. I will discuss the band, and in particular their Nazi-inflected third album, Secret Treaties, below. Here I just want to identify one track off this 1974, pre-popularisation of punk album. It is called 'Dominance and Submission'. and credited to Sandy Pearlman, Eric Bloom and Donald Roeser. While the lyrics, are characteristically obscure, the song seems to be about New Year's Eve 1963/4 and the narrator is observing an incestuous scene between Susan and Charles, sister and brother. At the heart of the song is the repetition of 'Dominance . . . submission'. Once again, without a connection being made clear, we have a Jewish singer meditating here literally - on dominance and submission. 
My final example of the preoccupation with dominance and submission is English. On the Sex Pistols' first album released in 1977, Never Mind the Bollocks, there is the Glen Matlock and Johnny Rotten composition, 'Submission'. The lyrics suggest a fascination on the part of the singer with a woman that he desires. In this case the song itself is of less interest than its origin. By 1975, when the song was written, Malcolm McLaren and Vivienne Westwood had named their shop in the King's Road, 'Sex'. They were specialising in clothing based on sadomasochism and bondage. As Savage writes: 'To go with the shop, McLaren told the group to write a song about submission: S \& M, bondage, domination, that sort of thing' (Savage 1992, pp. 128-9). The song lacks the urgency of those by Reed and Blue Öyster Cult, but then Lydon and Matlock were not Jewish. McLaren is, but he only ordered the song. Its purpose was to compliment McLaren's and Westwood's clothes. It is here, not directly in the music, that McLaren's post-Judeocide Jewish anxiety is being played out.

\section{Lou Reed}

If punk can be said to have originated in the work of the Velvet Underground, it is important to look at the careers of Lou Reed and Nico in more detail. It was Paul Morrisey with Andy Warhol who wanted to place Nico in the band. Warhol, the visual artist, was always concerned with the effect of an image. As Victor Bockris and Gerard Malanga write in their book on the Velvet Underground: 'Looked at from today it seems just right - the tall, thin, hauntingly beautiful blonde in a white suit standing in front of four thin guys (it took people some time to catch on that Maureen [Tucker] was [. . .] a chick) in black sunglasses' (Bockris and Malanga 1996, p. 96). Nico was not a natural blonde. She started dying her hair after she moved to Paris when she was seventeen. It made her look even more Aryan. In photographs of the Velvet Underground when she sang with them, Reed and Nico as the two singers would stand on either side of the stage, she in white, the rest of the band in black. He had his curly black hair and conventionally Jewish looks, her with her blonde hair and Germanic looks and, aurally, her German accent. It was a very powerful, but not at that time a marketable, image.

The penultimate track on The Velvet Underground and Nico is 'The Black Angel's Death Song' in which the lyric is intoned through John Cale's screeching viola. It was the discordant howl of this song that got the Velvets fired from their residency in Manhattan's Café Bizarre. Reed has only ever played the song once in his solo career and that was in 1972 when he, Cale and Nico performed together in Paris. As Jeremy Reed describes it:

[...] the epiphanic, apocalyptic overtones induce terror. There's no cohesive narrative, in the way that Reed usually addresses his subject with the skills of a short-story writer, but the jumbled incongruity of phrases carries the same discordant, bullying tone as the music and the surreal imagery in the song shocks by its disjunctive emphases. (Reed 1994, p. 37)

It is as if the weight of the subject, never addressed directly, breaks down narrative as, indeed, does trauma.

The lyrics begin by alluding to 'his fate'. They go on to describe what, apparently, this man cannot lose:

Not a ghost bloodied country

All covered with sleep

Where the black angel did weep

Not an old city street in the east

Gone to choose 
This dense web of imagery suggests a country in the east where the people have been destroyed; Poland perhaps, the Jewish population of the cities and shtetls destroyed by the Nazis. We can compare this with Sylvia Plath's 1962 poem, 'Mary's Song':

The same fire

Melting the tallow heretics,

Ousting the Jews.

Their thick palls float

Over the cicatrix of Poland, burnt out

Germany.

They do not die.

As 'The Black Angel's Death Song' unfolds so we have a reference to a rally man, perhaps Hitler's rallies, and to 'the cosy brown snow of the east', possibly Poland again. One line tells us that 'Sacrificial remains make it hard to forget'. In its original Greek, 'holocaust' refers to a burnt sacrifice. Plath makes the same connection in 'Mary's Song' where she makes the startling connection between the lamb Sunday roast and sacrifice. ${ }^{17}$ At this point in the 1960s, Jews were the main bearers of the memory of the Judeocide. It was yet to surface as a general Western cultural trauma. It is probably not worth continuing to try to elucidate the lyric of 'Black Angel's Death Song' in terms of the Judeocide. I do not want to suggest that this track is 'about' the Judeocide but, rather, that, as an apocalyptic lyric it draws on Reed's inchoate and unconscious reaction to the extermination. In this sense it is the closest Reed has come to confronting this trauma.

After the Velvet Underground broke up, Reed made two solo albums, the second of which, Transformer, produced by David Bowie, had a glam rock influence. His third solo album was Berlin, released in 1973. Reed had not been to Berlin. The album was recorded in London. It is, as Jeremy Reed writes, ' a death-oriented . . . set of songs' (Reed 1994, p. 87). By 1976/7 Berlin was to become a strong attractor for punk. In these years Iggy and David Bowie lived there and their albums Lust for Life, The Idiot and Low and Heroes were conceived there. In 1977 the Sex Pistols went to Berlin to escape the media frenzy in England (Savage 1992, pp. 340-1). It was while there that they wrote 'Holidays in the Sun' (ibid., p. 377) which contains the line: 'I wanna go to a new Belsen'. In 1978 the English punk band the Vibrators wrote their second album, V2, in Berlin. ${ }^{18}$ During this period Nico, drug-ravaged, was also spending time in Berlin. Bowie kept her away from Iggy. ${ }^{19}$ Berlin became an epicentre for, especially English, punk. The draw of Berlin for these artists is usually couched in terms of its freedom, its decadence, the youth of its population. However, what is not suggested is that Berlin had been the capital of Nazi Germany. At this time in the late 1970s, it was still a divided and occupied city. Here, then, we may be getting closer to its fascination, a fascination that seems to start with Reed's death-soaked album.

Berlin is more a song-cycle than a concept album. It works as a series of more or less interconnected tracks which tell the story of a relationship from the man's point-of-view. The only positive song is the first, called 'Berlin'. It is a description of the lovers in a café by the Berlin wall. The bulk of the album tells of the woman's drug addiction, the authorities taking away her children, and finally her suicide attempt, slitting her wrists in bed. The songs also describe the man's physical violence towards her. In 'Sad Song', the final track, the man turns away from her and leaves the relationship. 'Somebody else', he says, 'would have broken both of her arms'. 
Tricia Henry writes of 'Berlin's thematic allusions to the atrocities of wartime Germany (Henry 1989, p. 37). This is not something that immediately strikes the listener. Emotionally the album is very dark, very depressing. It plays out the loss of hope through its emphasis on the woman's despair. Nico believed that some of the songs were about her. John Cale denies this (Witts 1993, p. 150). Nevertheless, allowing for poetic licence, there are significant similarities. In 'Berlin' the woman is 'five feet ten inches tall', unusually tall for a woman, as was Nico (ibid., p. 35). ${ }^{20}$ In the following track, 'Lady Day', the woman sings in a bar, as Nico used to do in New York. Most tellingly, in 'The Kids' where the woman's drug-taking and sexual promiscuity lead to the loss of her children, Reed sings of a 'black air force sergeant [who] was not the first one'. Nico used to tell people that she had been raped in Berlin by such an American when she was thirteen. The point is not whether Berlin is based on Nico's life but, rather, how Nico, with her German background and complex relationship to the Nazi era, as especially signalled by her horror of the Judeocide, embodied for Reed the site for his own complex relationship to Germany, Germans and the Judeocide.

Berlin, with once again its theme of dominance and submission, can be read as Reed's unconscious attempt to work through his feelings about the Judeocide by means of a tale about a failed relationship. It is not surprising, then, that around the time of Berlin's release, Reed's look changed completely:

[...] his hair had been shorn in a crew-cut iron cross and he resembled an upwardly-mobile member of the Hitler jugend. Poor diet had made his figure lean, around this he wrapped bicycle chains and heavy buckles from boutiques such as Greenwich Village's Pleasure Chest. (Diane Clapton quoted in Henry 1989, p. 37)

Bangs offers a similar description, writing of Reed:

[. . .] shaving his traditionally kinky locks to the skull for the simian charm, then topping even his own act by carving Iron Crosses in that mangy patch of stubble [. . .] then [redoing] his dome Hitler Youth blond so he resembled a bubble-gum Kenneth Anger. (Bangs 2001, p. 170)

Bangs goes on to repeat a description of Reed from this time as:

something that belongs in an intensive care ward [. . . ] almost no flesh on the bones, all the flesh that is there sort of dead and sallow and hanging, his eyes are always darting all over the place, his skull is shaved and you can see the pallor under the bristles, [. . .] Everybody agreed they'd never seen anything as bad as this. (ibid., p. 171)

But they had, in the images of emaciated dead and living Jews from the liberated death camps. In his own traumatised acting-out of the Judeocide, Reed combined the experience of the Jewish victim with the look of the Nazi dominator.

\section{Nico}

Nico lived her life on uncertain ground, always revising her biography to express what she wanted to be in the present. Richard Witts subtitled his account, 'The Life and Lies of an Icon', an accurate but unfair description. After all, born in 1938, Nico lived the first seven years of her life as an included member of the Aryan race under a regime which she was subsequently told was evil and its practices immoral. As Witts writes: 'By her fifth birthday, on 16 October 1943, Christa had become an Aryan's dream, balloon-cheeked and blonde like a picture-book cherub' (Witts 1993, p. 13).

Nico was born Christa Päffgen in Cologne. Her father married for love and then was forced by his rich, Catholic family to divorce Nico's poor Protestant mother 
before the baby was born. Nico told many stories about her father, reflecting her own conflicts. She told her son that his grandfather was a Turk who died in Belsen for helping Jews (ibid., p. 2). This is an embellishment of her most usual story which was simply that her father had died in Belsen. He didn't. Wilhelm Päffgen was killed in action in 1942. In this same year, Grete took her daughter to live with her own parents in Lubbenau where her father worked on the railway. In later life Nico would tell stories about watching the trains carrying Jews to Auschwitz. ${ }^{21}$ This seems unlikely according to her cousin Ulrich who also lived in the house. However, the story expresses clearly how Nico's conflicted and guilt-ridden understanding of her childhood was most tellingly represented in her invocation of the Judeocide.

I have already mentioned Nico's rape narrative. In the story the black American, who may have been either an officer or a sergeant, was put on trial and, having been found to have committed a number of similar crimes, was executed. Nico told how she felt guilty about causing his death. Witts is cautious of this story. He could find no corroborating evidence (ibid., p. 32). Whether or not the events happened, the story works psychologically to give Nico a localised, and legitimate, trauma to displace the diffuse and more generalised trauma of her childhood. Within the narrative the black American, a member of that country's most well-known, stigmatised minority, stands in for the Jews and Nico's conflicted attitude to Jews is displaced onto him.

Living in Paris in her early twenties, Nico struggled with her lack of a solid, taken-for-granted cultural morality to inform her life by reading Nietzsche. While working as a model she was trying to understand nihilism through Jenseits van Gut und Bose (Beyond Good and Evil). Witts describes Nico at this time:

there was this mädchen, this Aryan German girl, clutching the work of one of Hitler's favourite philosophers. All she lacked was a riding crop. It wasn't only her looks, either. She liked to provoke a reaction in conversation by pretending to adore fascism, though always in a tone she considered ironic. (Witts 1993, p. 54)

One can only admire Nico's determination to deal with the moral crisis, and trauma, that unsettled her life.

By the time she met Dylan in 1964, Nico was an acclaimed model, a film actor, and had studied at the Actor's Studio in New York with Lee Strasberg. She had also had a son by the French film star Alain Delon. Dylan was two years younger than her. They met in Paris and immediately started an affair. They went on holiday to Greece together and Dylan wrote 'I'll Keep It With Mine' for her. Subsequently, Nico recorded it on her first solo album, Chelsea Girl, in $1967 .^{22}$

In 1965 Nico moved to New York and started frequenting Andy Warhol's studio, The Factory. It was then that Morrissey and Warhol persuaded the Velvet Underground to include her as a singer. Nico and Reed had a fairly brief liaison. Cale tells the story:

Lou and Nico had some kind of affair, both consummated and constipated. At that time he wrote these psychological love songs for her like 'I'll Be Your Mirror' and 'Femme Fatale'. When it fell apart, we really learnt how Nico could be the mistress of the destructive one-liner. I remember one morning we had gathered at the Factory for a rehearsal. Nico came in late, as usual. Lou said 'Hello' to her in a rather cold way, but just 'Hello' or something. She simply stood there. You could see she was waiting to reply, in her own time. Ages later, out of the blue, came her first words 'I cannot make love to Jews anymore'. (Witts 1993, p. 133)

Cale treats her comment as a piece of repartee. However, given her life, and the place the Judeocide had played in her attempt to find some moral certainty, we can understand Nico's remark as much more than this. Having relationships with Jews, 
Dylan and Reed, forced Nico to recognise that behind the event which was so important to her worldview were real people - and people whose lives were shaped in different ways by that same event. ${ }^{23}$ In 1969 she had an affair with that non-Jew Iggy Pop during and after the recording of the first Stooges album, which Cale produced. One suspects that Nico was attracted to Iggy's emotional pattern that fitted so well with Holocaust Jewishness. In his account of playing in Nico's backing band towards the end of her life, James Young recalls Nico saying, 'Lou never really liked me, [. . . ] because of what my people did to his people' (Young 1994, p. x).

Nico's second solo album, The Marble Index, released in 1969, was the first on which she wrote all the songs. It is a dramatic change from the earlier album. Here, we get for the first time Nico's sense of doom and despair which was to make her, retrospectively, a pioneer of the Goth sensibility. Cale produced the album. In the liner notes to the CD reissue, Richard Williams, the English rock critic, writes:

The Marble Index is one of the most uncompromising albums ever to be filed under rock: the first to abandon conventional structures and instrumentation, it was really the product of two European sensibilities - Nico's and John Cale's, the glacial mood and now-deepened voice of one allied to the astonishingly imaginative musicianship of the other.

On the web, terms like haunting, macabre and harrowing are used to describe the album. When The Marble Index was released, Williams wrote a review of it for the English music paper Melody Maker in which he said that:

The Marble Index is one of those records which just might in ten or twenty years time be regarded as some sort of milestone [...] the LP is a journey through a landscape not unlike Berlin, where she lived as a child: desolate and windblown, scarred yet futuristic. (quoted in Witts 1993, p. 230)

As Williams intuited, the album gives the impression of being nothing less than an inchoate expression of Nico's traumatised experience of her past. ${ }^{24}$

In the mid-1970s, as punk became popular, so Nico's singing career took on a new lease of life:

Nico was an international icon once more. She had been acclaimed as a punk paradigm by two new singers who led the field: Siouxsie Sioux of Siouxsie and the Banshees and Patti Smith. (Witts 1993, p. 277)

In England, Nico performed on the same bill as the Adverts and was booked to open for Siouxsie and the Banshees first British tour. Recognising punk's musical connection with the Velvet Underground, Nico felt herself to be 'a proud mother' (ibid., p. 276).

By 1979 she was acknowledging the importance of Sylvia Plath. In 1985 she said: 'There is a poet in America who wrote about my childhood. Do you know this poem? I call it "Lazy Lady". Isn't that me?' (ibid., p. 202). ${ }^{25}$ The poem is 'Lady Lazarus'. Plath identified as a Holocaust Jew. 'Lady Lazarus' imagines her the daughter of a Jew and a Nazi father. Nico seems, by this time, to have believed her own imaginary origin: part Jew, part Nazi. Nico legitimated her conflicted and traumatised life in this mythic personal origin.

\section{Blue Öyster Cult and The Dictators}

Previously, I located Blue Öyster Cult as a part of the pre-history of 1970s punk; however, BOC are best known as a pioneering American heavy metal band. On the biggest $\mathrm{BOC}$ internet website, they are described as 'a rock band whose destiny was 
no less than to bring ultimate meaning to the concept of heavy metal' ${ }^{26}$ However, another website positions BOC historically like this:

Long before Pearl Jam, Soundgarden and Stone Temple Pilots ruled the heavy metal airwaves, this Long Island-based band [. . .] made tightly wound, whip-cracking arena rock, its dark S \& $\mathrm{M}$ imagery a forerunner of today's would be hip nihilist blank X generationism. ${ }^{27}$

The author goes on to identify BOC as '[t]he missing link between the Velvet Underground, KISS and the nascent punk-rock movement of the late '70s'. Rather than only in generic musical terms, this writer is considering the common philosophical concerns that link the Velvet Underground, BOC and the later punk bands such as Richard Hell and the Voidoids.

Earlier, also, I mentioned that it is unclear how many of BOC were Jewish, certainly the lead singer. In addition, though, we have to recognise Sandy Pearlman's influence. As the BOC website puts it: 'As producer, songwriter, and manager of BOC, Pearlman's knowledge of history and philosophy have enjoyed free reign for nearly 20 years'. Pearlman was a philosophy major at Stony Brook, State University of New York, on Long Island. He has also been a Woodrow Wilson Fellow in the History of Ideas. Pearlman is credited with inventing the term 'heavy metal' during his stint as a rock critic on Crawdaddy. ${ }^{28} \mathrm{He}$ invented the name Blue Öyster Cult, including the Germanic umlaut on the $\mathrm{O}$ of Oyster, and also thought of using the Greek sign for Kronos as the logo for the band. In other words, BOC were very much a vehicle for Pearlman's ideas. The other major influence on the band was also Jewish. Richard Meltzer, too, had studied philosophy at Stony Brook. He became a rock critic and also wrote lyrics for BOC. BOC's self-titled first album was released in 1972; it contained five tracks co-written by Pearlman and two by Meltzer.

The lyrics on this album are a melange of Satanism and madness as in 'Screams', murder in 'Last Days of May', and a retelling of the notorious Rolling Stones Altmont concert from the point of view of the Hells Angels hired to patrol it on 'Transmaniacon M.C'. ${ }^{29}$ Here, once more, we have a Jewish lead singer singing mostly from the subordinate position of extreme threat and anguish. He sings 'unknown terror's here' and 'We're the pain, we're steel, a plot of knives'. The second album, released in 1973, makes the terror of those subject to extreme power more obvious in its title, Tyranny and Mutation. This album contains a track called 'Hot Rails to Hell'. Post-1978 and the high salience of knowledge about the Holocaust, including the use of railways to transport the Jews, it is hard to think of this title any other way. However, while the lyrics set up an atmosphere of great ominousness, for example, 'Blackened-out eyes scratched on a wall', there is no more direct suggestion of the Judeocide. The nihilism of the band, confused through an array of horrific themes, does not confront its ultimate source.

On BOC's third album, the band comes as close as it ever would. Secret Treaties was released in 1974. At some level Pearlman had been preoccupied with Nazism since BOC's inception. I have already mentioned the umlaut. Kronos' sign is like an upturned question mark with a bar across the centre. It echoes, but is not totally similar to, a swastika. The hesitation about using the swastika can be found later in the Ramones. Arturo Vega was artistic consultant for the band. He describes their music as 'an exploration of the dark side'. He goes on:

The swastika is a symbol, like the eagle. I was wearing fluorescent swastika armbands in 1973. I told Tommy I was going to use a photograph of an eagle and a swastika for the Ramones, he had all sorts of reservations about that. (True 2002, p. 58) 
The liner notes for Secret Treaties mention a non-existent book, The Origins of a World War. Yet even on this album, BOC only have one track which directly connects with the Second World War. This is 'ME262', a song from the point of view of a successful Luftwaffe pilot.

Other tracks suggest Hitler, 'Career of Evil', and the Judeocide, 'Subhuman', but the lyrics steer well clear of these topics. While 'Subhuman' is written from the point of view of somebody considered to be subhuman, 'Career of Evil' revels in a first-person celebration of evil, as in:

I choose to steal what you chose to show

And you know I will not apologise

Nevertheless, even this lyric is quite anaemic when compared to the Ramones' 'Today Your Love, Tomorrow The World' which was released only two years later. Secret Treaties also contains 'Dominance and Submission' discussed earlier. A 1975 Penthouse article by Lester Bangs on 'The New Prefab Nihilism' notes that:

Pearlman once said that the epiphanous turning point in [BOC's] career came when they were banging out the Stones' 'Under My Thumb' and, as he put it: 'It hit me that "Under My Thumb" and the whole twentieth century were about dominance and submission'. (Bangs 1975)

In spite of the album's blandness by (post-)punk standards, it was enough to get BOC's concerts picketed by the Jewish Defence League and to have record stores in Germany refuse to stock it. On the BOC website Albert Bouchard tells of 'a gig in Portland, Oregon, [where] this blond, blue-eyed guy came up in full SS [. . .] uniform, saluting us. He freaked us all out'. Suggesting their similarity in musical style, KISS's first major gig was at a 1973 New Year's Eve show where they opened for BOC. ${ }^{30}$ The connection between BOC and 1970s punk is made clear in The Dictators, retrospectively dubbed the first punk band. ${ }^{31}$

The Dictators were a predominantly Jewish group founded by Andy Shernoff who was also the lyricist and played bass guitar. In 1972, when he was nineteen, Shernoff started a mimeographed fanzine called Teenage Wasteland Gazette and subsequently wrote for Creem. True tells us that Shernoff 'wrote about bands like Blue Oyster Cult and the Velvet Underground in his fanzine' (True 2002, p. 29). The Dictators formed in late 1972. As a band made up of Jews, their name already signals a much clearer sense of their relationship to the Second World War, and by implication the Judeocide. In 1973, through Richard Meltzer, the band met and recorded a demo for Sandy Pearlman and Murray Krugman. ${ }^{32}$ In November 1973 The Dictators played their first professional gig, opening for Iggy and the Stooges and Blue Öyster Cult at the Prince George Community College in Maryland.

By 1974 when the band recorded their first album, released the next year, The Dictators Go Girl Crazy!, their front man was their ex-roadie, Richard Blum, who performed as Handsome Dick Manitoba. Manitoba gave the band the aggression that became typical of punk. As 'The Dictators Story' tells it: 'He caused a lot of the trouble that got them thrown out of the press parties they'd connive their way into 'cause he' $d$ eat so many 'ludes [Qualudes]'. Manitoba also got the band banned from playing Max's Kansas City after he heckled the transsexual singer Wayne County with an alleged homophobic remark while County was on stage at CBGB's. County broke Manitoba's collar-bone. ${ }^{33}$ Manitoba was no singer but he provided an assertive nihilism to counterpoint The Dictators' catchy and humorous hard rock reworking of American pop. The Dictators Go Girl Crazy! begins with an out-take from a concert where, amidst applause, Manitoba tells the audience: 
I don't have to be here, you know. I don't have to show up here. With my vast financial holdings I could have been basking in the sun in Florida. This is just a hobby for me. Nothing, you hear; a hobby.

Manitoba was also renowned for throwing French fries at the audience and shouting 'Rock'n'roll? BAH!! Who needs it?!' (Holmstrom and Rosenthal 1977). None of this is as spectacular as Iggy's apocalyptic, nihilistic self-mutilation. It is, however, a negative aggression turned outwards towards the audience. It undercuts the very meaningfulness of the rock performance and places it in question.

In 'The New Prefab Nihilism' The Dictators are described as being:

as exciting as the Blue Öyster Cult were at first. But where the Cult are almost ludicrously 'sinister', the Dictators have made sure their aggression is liberally seasoned with a marvellous sense of humour. They sound like the MC5 with the New York Dolls' David Johansen singing lead; in other words their music is fast and furious and filled with a raunchy exaltation. (Bangs 1975)

In later punk, the music would get faster, the aggression and nihilism would increase and, with the exception of the Ramones, the humour would disappear. At bottom, the humour of The Dictators Go Girl Crazy! is founded in a Jewish interaction with the values and mores of white American teenage culture, and with the pop music that feeds its fantasies. On '(I Live For) Cars And Girls', the final track, the fun of the Beach Boys-style harmonies comes only partly from recognising the song's ironic pastiche of white American pop. It also comes from knowing the song is being performed by a group of American Jews for whom such a performance of whiteness is utterly incongruous. ${ }^{34}$ The Beach Boys could never be Jewish. ${ }^{35}$

While much of The Dictators' work engages with white American teen culture, it is still the product of that same post-Judeocide generation as the other artists discussed, a generation who found their voice, their visibility and their trauma. 'The Next Big Thing', the Shernoff track which begins Girl Crazy!, expresses this well. It starts:

I used to shiver in the wings

But then I was young

I used to shiver in the wings

Till I found my own tongue

Here Shernoff can be read as writing about the anxiety of being visible, of being onstage, and about not being able to speak about how the Jews of his generation felt. Later, with a clear assertion of the irony about the band's Jewishness, the lyrics continue:

I knocked 'em dead in Dallas

And I didn't pay my dues

Yeah, I knocked 'em dead in Dallas

They didn't know we were Jews

Clearly, we wouldn't have knocked them dead in Dallas if they had known we were Jews. At the same time, not telling them we're Jewish is now a clever tactic - I didn't pay my dues - not an attempt at assimilation. The implication seems to be that in the end the band don't care about success in Dallas. Having found their (Jewish) voice, they are going to be the Next Big Thing. They are going to be hugely visible - like KISS, perhaps.

If the bulk of Go Crazy! deals in white American teen culture, as its title suggests, the Judeocide was nevertheless still not far away. Perhaps the most extraordinary 
track on the album is 'Master Race Rock'. In this song, sung in the first person plural, the 'we' amalgamates Jews and white Americans, suggesting again ironically, that this youth is the master race. The first chorus tells us that:

We're the members of the master race

Got no style and we got no grace

Sleep all night, sleep all day

Nothing good on TV anyway

The song is an ironic celebration of American youth. Appropriating the idea of the master race for this purpose simultaneously deflates the term's significance, its resonance with Nazi ideology and, in offering an uncanny reference to the Judeocide, marks the horror of that Nazi usage.

The Dictators remained a critic's band, a band praised for its achievement in offering a commentary on American teen culture while balancing a nihilist attitude with musical excitement; a band that pointed the way to the musical form that would become known as punk. As Mark Deming writes in his review of The Dictators Go Girl Crazy! on the All Music Guide website: 'Dozens of groups borrowed wholesale from The Dictators Go Girl Crazy! later on down the line, but the original is still the greatest [...] and the funniest'.

As I have already indicated, the Ramones were well aware of The Dictators. Joey Ramone, at least, used to watch their gigs. The photographs on the inside of the Girl Crazy! CD cover show The Dictators wearing the leather jackets that would become a part of the Ramones' trademark costume. True quotes John Holmstrom, founder of Punk magazine: ' "Listen to The Dictators singing 'C'mon boys [sic], let's go' from 'Master Race Rock' and then tell me if it's not where Joey or Dee Dee got the Ramones' 'Let's go' from"' (True 2002, p. 29). ${ }^{36}$ The Dictators covered 'California Sun' (originally released by Joe Jones in 1961 but better known in the version by the Rivieras released in 1964) on Girl Crazy! as the Ramones did on their second album, Ramones Leave Home (1977). Shernoff generously says of the Ramones:

It was surf music, it was pop, it was hard rock - with a big beat. We obviously had the same influences but they sharply focused them and cut out the fat. (True 2002, p. 29)

In addition, the Ramones had both Joey and Dee Dee, the Jew haunted by the Judeocide and the man haunted by his youth in Germany.

In the end the preoccupations of Shernoff, and the rest of the Jewish Dictators, were too American, too bound up with the myths of white American youth from which, as Jews, they were excluded. The Ramones were emotionally closer to the apocalyptic nihilism which has its roots in the Velvet Underground and comes to light in 1970s punk made by both Jews and Gentiles. This is the nihilism that is an expression of the cultural trauma of the Judeocide. The climactic years for punk were 1975 to 1977. The Ramones released their first album in 1976, the year after The Dictators Go Girl Crazy!. Also in 1976, Pere Ubu, the Cleveland band of which singer David Thomas was a cofounder, released their second single titled 'Final Solution'. One website describes the track as 'a deconstruction of Eddie Cochran's rockabilly classic "Summer Time Blues" [based on] Blue Cheer's bikers-on-acid psychotic fuzz freakout cover version'. Reworking Cochran's paean of male teenage angst, the song's chorus climaxes with the singer asserting that: 'I don't need a cure [. . .] I need a final solution' (21st Century Rock'n'Roll Boy [n.d.]). As with The Dictators, there is a link between American teen concerns and the Judeocide. Here, though, Cochran's song is reinscribed in punk's nihilistic register using the term that Hitler himself had applied 
to the extermination of the Jews. If this sounds far-fetched, we should note that Pere Ubu used to play the Extermination Music Nights at the Viking Saloon in Cleveland in December 1974 and January 1975. ${ }^{37}$ While The Dictators were coming to terms with the Nazi genocide from a Jewish perspective, the Pere Ubu song's utilisation of the Judeocide trope is rather more ambiguous. Even within the lyrics one wonders if the first person narrator is asking for a final solution that will affect the adults around him, or asking not for a cure for himself but for something much more final. The band's first album, The Modern Dance (1978), which, for whatever reason does not contain 'Final Solution', is generally regarded as one of the key albums in the genealogy of punk.

In 1977 in England, the Sex Pistols released Never Mind The Bollocks and, in the United States, Richard Hell and the Voidoids released Blank Generation. In a howl of agony 'Blank Generation' begins, 'I was sayin' let me outta here before I was/even born'. 'Blank Generation' was written early in 1975 (Savage 1992, p. 90). It was the inspiration for the Sex Pistols' much better-known 'Pretty Vacant' which was released as a single in 1977 and which can also be found on Never Mind The Bollocks (ibid., p. 126). Hell's lyrics carry a much greater weight of personal, and cultural, trauma. This is a generation that is blank not because of anything that has happened in the lives of its members, but something that happened before Hell and his generation was born. In 1978 the Holocaust mini-series was shown across Europe. As Jeffrey Shandler writes: 'the response to its broadcast in the United States and abroad arguably proved to be a more noteworthy cultural landmark than the miniseries itself' (Shandler 1999, p. 159). The cultural trauma gained a name, and a popular acknowledgement. At least in part, punk is the affective expression of that cultural trauma before it was acknowledged and named. Jews played an important part in punk's development. More generally, the development of punk, not just as a musical form but as an attitude to life, needs to be placed in the context of the developing awareness across the West of the Judeocide, and the narrativising of this as the Holocaust.

\section{Copyright Acknowledgement}

Lyrics from 'Master Race Rock' reproduced by kind permission of Adny Shernoff.

\section{Endnotes}

1. The most useful discussion of cultural trauma is to be found in Alexander et al. (2004).

2. I discuss some aspects of this unsettling, as they apply to colonialism, in Stratton (2003).

3. Lyotard (1987, pp.14-15) doesn't name the Holocaust but argues that the Nazis destroyed, or at least through their practices undermined, the ideals of the 'modern project'. Andrea Huyssen spells out the connection in Huyssen (1994).

4. Donald Bacigalupi (1993, p. 126) argues that: 'The violence embedded in Punk style was an extreme extension of the glam rockers and their perfection of the "pos[e] ... as performance art" '.

5. One story about Bolan's name is that he so highly respected (the Jewish) Bob Dylan that he chose the first two and last two letters of Dylan's stage name, putting them together to form Bolan.
6. One presumes that Shernoff, himself Jewish, was commenting more on the similarities in the Starship/Mercury costumes than in their non-'white' looks - Mercury was born Farokh Bulsara in Zanzibar. His family were Indian Parsees. In a personal communication, Shernoff tells me that, in fact, there was a miscommunication with True. Shernoff was actually referring to the singer in Sniper after Joey. However, he makes the point that at this time Joey was wearing satin and clothes identifiable as glam.

7. See the interview with Sylvain Sylvain at http: / / www.canoe.ca/JamMusicArtistsN/ newyorkdolls.html where there is also the biographical material given earlier.

8. Savage (1992, pp. 88-9) has this history.

9. In 1976, Hell played the lead in a fumetti (an adult comic that can use photographs rather then cartoons) written and directed by Legs 
McNeill. This appeared as issue 6 of Punk magazine: 'It told the story of Nick Detroit, former top international Agent and super-killer now become world-weary mercenary battling the infamous Nazi Dykes and their schemes for world domination' ('The Legend of Nick Detroit' at: <http:/ / www.richardhell.com/

nickdetr.html >). Here, Hell, the Jew battles, and wins, against the new Nazis, a traumatic reenacting of Jew and Nazi with the Jew saving the world this time rather than being slaughtered. Should there be any doubt about the Nazi Dykes, a swastika appears on the comic's cover.

10. See, for example, Tony Kushner (1989) and David Cesarani (ed.) (1990).

11. Bill Coxall and Lynton Robins (1998, p. 37) tell us that: 'Inflation rose by 26.4 per cent . . . in 1974. In 1976 confidence in sterling collapsed again, and when the pound sank to $\$ 1.70$ the government was forced to seek a loan from the IMF. ... [The terms] proved to be harsh: in return for a $\$ 3$ billion loan the government was forced to make massive public expenditure cuts of over 2.5 million pounds in 1977-8 and 1978-9'.

12. This can be heard well on the climactic end of the lengthy version of 'Open Up And Bleed' on the Iggy Pop and the Stooges bootleg live album, Live in $L A$ ' 73 , where rhythm, melody and tone are lost. In his web review of the Stooges' released material, Ken Shimamoto writes of this version as the cataclysmic 13 minute "Open Up And Bleed" '.

13. While few of the significant musicians in the punk scene are usually said to have committed suicide (Joy Division's Ian Curtis, who hung himself in 1980, is one exception; another possible one is Peter Laughner of Rocket from the Tombs and Pere Ubu), there was a great deal of serious drug abuse, and many overdoses on heroin. The punk duo, Suicide, came out of New York in the early 1970s. Their first self-titled album was released in 1977. Thinking about names, we can also name-check the Cleveland band, The Dead Boys, who released their first album, Young, Loud and Snotty, in 1977. '3rd Generation Nation', a track from their second album, begins: 'There ain't no future and there ain't no past/There's just a graveyard and it's coming fast'. 3rd generation here would seem to refer to being the descendants of migrants to the United States. However, the affect feeds off the increasing awareness of the Judeocide.

14. I have already noted that Richard Hell took his name from Rimbaud's (2000) book, Un saison d'enfer. In that book, in a section called 'The Foolish Virgin', Rimbaud writes: 'I listen to him turn infamy into glory, cruelty into charm. "I belong to an ancient race: my ancestors were Norsemen: they slashed their own bodies, drank their own blood. - I'll slash my body all over, I'll tattoo myself, I want to be as ugly as a Mongol: you'll see, I'll scream in the streets. I want to get really mad with anger. Don't show me jewels; I'll get down on all fours and writhe on the carpet. I want my wealth stained all over with blood. I will never do any work . .."' Rimbaud was writing out of his own traumatic experience of his romantic break-up with Verlaine. Hell identified with Rimbaud's expression of trauma; Iggy acted out Rimbaud's description of traumatised self-disgust.

15. In 'Pretty Vacant', Bacigalupi positions Iggy in a history of self-mutilation in performance art.

16. This information comes from True (2002, pp. 14-15).

17. The lamb is a particularly rich image here suggesting both the Passover sacrifice and Jesus as the redemptive lamb of God.

18. The Berlin Philharmonic Orchestra play on the track 'Nazi Baby'.

19. This story is told by Richard Witts in Witts (1993, pp. 273-4).

20. Witts writes that Nico was five feet eleven inches tall (ibid., p. 95).

21. All this background information on Nico's life comes from Witts (1993), Chapter One.

22. It is said that Dylan wrote 'Visions of Johanna', which appeared on his album Blonde on Blonde (1966), about Nico.

23. Leonard Cohen used to watch Nico perform at Stanley's, the cellar bar of the Dome, in New York in 1966. It is sometimes claimed that his singing style owes a lot to hers. Cohen has said that he wrote 'Take This Longing' with Nico in mind, and, indeed, that he gave her the song but that she never recorded it. The song appears on Cohen's 1975 album, New Skin for Old Ceremony. One wonders what this Jew (thought he) found so fascinating in the image of this traumatised German woman with the Nazi childhood performing her songs of anguish-songs that would later have her acclaimed as a forerunner of the Goth subculture.

24. The title comes from the Third Book of 'The Prelude' by William Wordsworth (1770-1850), the English Romantic poet: 'The antechapel where the statue stood/Of Newton, with his prism and silent face/The marble index of a mind for ever/Voyaging through strange seas of Thought, alone'.

25. Witts takes Plath's fantasy biography as real.

26. Hellenic Cult website: <http://www.geocities. com/greekharvester/BOC_history_in_English. doc $>$

27. The Catalyst website: <http:/ / www.catalystclub. com/bios/boc_bio.html>

28. Pearlman published a four-page article about the Velvet Underground in Crawdaddy, no. 16, 1968, which suggests, at the least, the influence of that band's thematic concerns on him.

29. It is still worthwhile to read Lester Bangs' 1972 review of this album. It can be found at: <http:/ / www.superseventies.com/spblueoystercult2. html>

30. Iggy and the Stooges were on the same bill. Heylin (1993, p. 182) goes so far as to describe the Dictators and BOC as glam rock bands.

31. Sandy Pearlman's biography describes The Dictators first album, The Dictators Go Girl 
Crazy, as 'arguably the first "punk" record'. This biography can be found at: <http:/ / www. breathingprotection.com/ sandy_pearlman.htm>

32. This information on the history of The Dictators comes from 'The Dictators Story' by John Holmstrom and Mark Rosenthal, originally published in the magazine Punk in 1977. It can be found at: <http://members.aol.com/ dffd1234/punkmag.html>

33. This story is told in a number of places, one is Heylin (1993, p. 185). Another version is in Holmstrom and Rosenthal's 'The Dictators Story'.

34. 'Cars and Girls' is a prescient commentary on much of Bruce Springsteen's output in the 1970s.

35. 'Weird $\mathrm{Al}^{\prime}$ Jankovic is a Jewish artist who has made a career out of parodic reworkings of American pop.
36. A pedantic note; the line to which Holmstrom is referring is actually, 'C'mon guys, let's go'.

37. In From the Velvets to the Voidoids, Heylin writes that: "The title of "Final Solution" hinted at one aspect of Cleveland's alternative scene that in later years its members have been keen to downplay - a flirtation with the imagery of fascism, something closely paralleled in the early British punk scene. Though Thomas would go to great lengths to deny the connection ... the swastika symbol was evident in the poster for the Special Extermination Night as well as on Johnny Madinsky's drum kit' (Heylin 1993, p. 149). Heylin is writing about the song as performed by the band out of which Pere Ubu evolved, Rocket from the Tombs.

\section{References}

21st Century Rock'n'Roll Boy. [n.d.] 'The Greatest Rock and Roll Records Ever: "Final Solution" by Pere Ubu', <http:/ / www.secraterri.com/ final.html>

Alexander, J. et al. 2004. Cultural Trauma and Collective Identity (Berkeley)

Arendt, H. 1994. Eichmann in Jerusalem: A Report on the Banality of Evil, revised and enlarged edition (New York)

Attali, J. 1985. Noise: The Political Economy of Music, trans. Brian Massumi (Minneapolis)

Bacigalupi, D. 1993. Pretty Vacant: Neo-expressionist Painting, Situationist Theory, and Punk Rock, Ph.D. Thesis (University of Texas at Austin)

Bangs, L. 1975. 'The New Prefab Nihilism', Penthouse, <http://members.aol.com/dffd1234/penthouse. html>

2001. Psychotic Reactions and Carburetor Dung, ed. G. Marcus (London)

1972. Review of Blue Oyster Cult, Super Seventies RockSite, <http://www.superseventies.com/ spblueoystercult2.html>

Bockris, V., and Malanga, G. 1996. Uptight: The Story of The Velvet Underground (London)

Burchill, J. 1978. 'Siouxsie and The Banshees The Scream', New Musical Express, 18 November, <http:// website.lineone.net/jon,simmons/julie/siouxnme.htm>

Carr, K.L. 1992. The Banalization of Nihilism: Twentieth Century Responses to Meaninglessness (Albany)

Caruth, C. 1996. Unclaimed Experience: Trauma, Narrative, and History (Baltimore)

The Catalyst website. <http://www.catalystclub.com/bios/boc_bio.html>

Cesarani, D. (ed.) 1990. The Making of Modern Anglo-Jewry (Oxford)

Clapton, D. 1983. Lou Reed and the Velvet Underground (New York)

Cohen, L. 1963. The Favourite Game (Toronto)

1964. Flowers for Hitler (Toronto)

1966. Beautiful Losers (Toronto)

Coxall, B., and Robins, L. 1998. British Politics since the War (Houndmills, Basingstoke)

Deming, M. [n.d.] 'The Dictators Go Girl Crazy', All Music Guide, <http://www.allmusic.com/cg/ amg.dll>

Eyerman, R. 2001. Cultural Trauma: Slavery and the Formation of African American Identity (Cambridge)

Grjibovsky, V. [n.d.] 'Death in the Works of Theodor Adorno, Elias Canetti and Levinas', <http:// rosenzweig.huji.ac.il/Staff/grjibovsky.htm>

Hellenic Cult website, <http://www.geocities.com/greekharvester/ BOC_history_in_English.doc>

Henry, T. 1989. Break All Rules!: Punk Rock and the Making of a Style (Ann Arbor)

Heylin, C. 1993. From the Velvets to the Voidoids: A Pre-Punk History for a Post-Punk World (London)

Holmstrom, J., and Rosenthal, M. 1977. 'The Dictators Story', Punk, <http://members.aol.com/dffd1234/ punkmag.html>

Huyssen, A. 1994. 'Monument and memory in a postmodern age', In The Art of Memory: Holocaust Memorials in History, ed. J. Young (Munich), pp. 9-17

Kushner, T. 1989. The Persistence of Prejudice: Antisemitism in British Society During the Second World War (Manchester)

'The Legend of Nick Detroit', <http:/ / www.richardhell.com/nickdetr.html>

Lyotard, J.-F. 1987. 'Ticket to a New Décor', Copyright 1.10, pp. 14-15 
Margalit, A., and Motzkin, G. 1996. 'The uniqueness of the Holocaust', Philosophy and Public Affairs, 25/1, <http:/ / www.codoh.com/reference/uniqofholo.html>

Marsden, J. 2000. 'Interminable Intensity: Nietzsche's demonic nihilism', in Evil Spirits: Nihilism and the Fate of Modernity, ed. G. Banham and C. Blake (Manchester)

McNeill, L., and McCain, G. 1996. Please Kill Me: The Uncensored Oral History of Punk (New York)

Novick, P. 1999. The Holocaust in American Life (Boston, MA)

O'Hara, C. 1999. The Philosophy of Punk: More Than Noise, 2nd edn (Edinburgh)

Paytress, M. 1992. Twentieth Century Boy: The Marc Bolan Story (London)

Pop, I., with Wehrer, A. 1982. I Need More: The Stooges and Other Stories (Princeton)

Rawin, N. 1993. 'Writing Around the Holocaust: Uncovering the Ethical Centre of Beautiful Losers', <http:/ / www.arts.uwo.ca/canpoetry/cpjrn/vol33/rauvin.htm>

Reed, J. 1994. Waiting for the Man (London)

Rimbaud, A. 2000. 'Un saison d'enfer' [A Season in Hell], in Complete Works, trans. P. Schmidt (New York)

Rotundo, E.A. 1982. 'Jews and Rock and Roll: a study in cultural contrast', American Jewish History, 72

Sabin, R. (ed.) 1999. Punk Rock: So What? The Cultural Legacy of Punk (London)

'Sandy Pearlman', Breathing Protection Inc., <http://www.breathingprotection.com/ sandy_pearlman.htm>

Savage, J. 1992. England's Dreaming: Anarchy, Sex-Pistols, Punk Rock and Beyond (New York)

Shandler, J. 1999. While America Watches: Televising the Holocaust (New York)

Shimamoto, K. 2002. 'Now Let Us Praise Famous Stooges', <http://www.i94bar.com/sixteen/ stoogeboots.

html>

Simmons, G. 2001. KISS and Make-Up (New York)

Simmons, S. 2001. Serge Gainsbourg: A Fistful of Gitanes: Requiem for a Twister (London)

Stratton, J. 2000. Coming Out Jewish: Constructing Ambivalent Identities (London)

2003. 'It Almost Needn't Have Been the Germans: the state, colonial violence and the Holocaust', European Journal of Cultural Studies, 6/4, pp. 507-27

Sylvain Sylvain. 2000. Interview, <http:/ / www.canoe.ca/JamMusicArtistsN/ newyorkdolls.html>

True, E. 2002. Hey Ho Let's Go: The Story of the Ramones (London)

Witts, R. 1993. Nico: The Life and Lies of an Icon (London)

Young, J.E. 1990(1988). Writing and Rewriting the Holocaust: Narrative and the Consequences of Interpretation, 1st Midland edn (Bloomington)

Young, J. 1994. Nico: The End (New York) 